\title{
TOLAKI TRIBE'S MARRIAGE: The Struggle of Islamic Law and Customary Law
}

\author{
Ipandang1, Ai Yeni Yuliyanti² \\ 'State Institute for Islamic Studies (IAIN) Kendari, Indonesia \\ Jl. Sultan Qaimuddin No.17, Baruga, Kota Kendari, Sulawesi Tenggara 93563 \\ E-mail: ipandangiainkendari@gmail.com \\ ${ }^{2}$ State Islamic University (UIN) Sunan Gunung Djati Bandung, Indonesia \\ Jl. A.H. Nasution No. 105A, Cibiru,, Bandung, Jawa Barat \\ E-mail: yeni.yuliyanti@uinsgd.ac.id
}

\begin{abstract}
This study aims to understand the history and struggles of Islamic law and Tolaki culture in the munakahat figh, inherited from the Tolaki community as contained in the Tolaki customary law structure. This study uses a qualitative descriptive method and a phenomenological approach. This research shows that the struggle of Islamic law and marriage culture in the Tolaki community is that the relationship between Islam and Tolaki culture shows adaptation, mutual understanding, and conversation. This relationship means no dominant or mutually dominant camps in this cycle of marriage, Islam, and traditions. Thus, there is a need for the role of traditional leaders, religious leaders, community leaders, and the government to socialize intensely the importance of cultural values in society, nation, and state to preserve existing culture for the continuity of future generations in various activities.
\end{abstract}

Keywords: local culture; mainstreaming; munakahat figh.

\begin{abstract}
Abstrak: Penelitian ini bertujuan untuk memahami sejarah dan pergumulan tentang hukum Islam dan budaya Tolaki dalam fikih munakahat yang diwariskan kepada masyarakat Tolaki yang terdapat dalam struktur hukum adat Tolaki. Dengan menggunakan metode deskriptif kualitatif dan pendekatan fenomenologi, Hasil penelitian menunjukkan bahwa pergumulan hukum islam dan budaya perkawinan pada masyarakat Tolaki adalah hubungan antara Islam dan budaya Tolaki menunjukkan adaptasi, saling pengertian dan percakapan satu sama lain. Artinya, tidak ada kubu yang dominan atau yang saling dominan dalam siklus pernikahan, Islam, dan tradisi ini. Untuk itulah perlunya peranan tokoh adat, tokoh agama, tokoh masyarakat maupun pemerintah secara intens dan berkelanjutan dilaksanakan berbagai kegiatan yang mensosialisasikan pentingnya nilai-nilai budaya dalam kehidupan bermasyarakat, berbangsa dan bernegara guna melestarikan budaya yang sudah ada demi kelangsungan generasi mendatang.
\end{abstract}

Kata Kunci: budaya lokal; pengarustamaan; fikih munakahat.

\section{Introduction}

Islam exists in a diverse cultural territorial space. The differences cause the cultural accommodation between Islam and local culture that get Islam has a role in the cultural collaboration between Islam and local traditions. The discourse that makes Islam intertwined with culture and history gives rise to new mosaics with local patterns and dispositions. Therefore, the interpretation of a text is influenced by social and cultural factors of society. For instance, the concept of qawl jadid and qawl qadim in the religious view of Imam Shafi'i. It clearly shows the existence of cultural determinism factors for the interpretation of religious texts in studying the historical space of Muslims. ${ }^{1}$

The accommodation of Islam in the local culture is increasingly visible when the Islamic region has developed and some people in all parts of the world convert to Islam. If the atmosphere

${ }^{1}$ Muhammad Alifuddin, "Fikih Keraton: Diskursus Hukum Islam Dalam Bingkai Tradisi Lokal Masyarakat Buton,” Istimbath, (2014), p. 23. 
of accommodation occurs, there are two variants of Islam listed in different terms, namely the reality conception Islam and local traditions Islam. A broad tradition or practice, for example, that describes Islam is essentially a conception of reality and a minor or local tradition. Or in other words "Islam" and "Islamicate" fields that are "Islamic" which is influenced by Islam."

The relation between Islam and the local culture has become an interesting study for academics. Many scholars have examined the struggle of Islam and some local cultures in Indonesia. In Gorontalo community, there is Mopo'alati Tradition which experiences struggles with Islam;3 Betawi community with its cultural hybridity which has historically been shaped by various ethnicities and religions in a cosmopolitan cultural space; ${ }^{4}$ Towani Tolotang community can make cultural accommodation with Islamic teachings and Towani Tolotang; 5 Sundanese society acculturation and assimilation between Sundanese culture and Islamic teachings that put Islamic religious values in a central position in all aspects of their life, as the Sundanese philosophy of life in the expressions Silih Asah, Silih Asih, Silih Asuh. ${ }^{6}$

The acceleration of Islam with local culture is a description of how Islam becomes universally normative teaching and then humans interpret it through a cultural process without losing their respective identities. ${ }^{7}$ As a reality, local culture aims

2 Azyumardi Azra, Konteks Berteologi Di Indonesia: Pengalaman Islam, (Jakarta: Paramadina, 1999), p. 13.

${ }^{3}$ Rahmawati Rahmawati, Kasim Yahiji, and Muh Rusli, "Mopo'alati Tradition In The Coastal Muslim Community At Molotabu Beach Bone Bolango District," Wawasan: Jurnal Ilmiah Agama Dan Sosial Budaya, vol. 4, no. 1 (December 2019), pp. 65-79, https://doi.org/10.15575/jw.v4i1.4080.

${ }_{4}^{4}$ Deni Miharja, M. Mulyana, and Ahmad Izzan, "Islam, Ethnicity and Cultural Politics of Identity: The Religiousity of Betawi Muslim in Jakarta," Wawasan: Jurnal Ilmiah Agama Dan Sosial Budaya, vol. 4, no. 2 (December 2019), pp. 132-43, https:// doi.org/10.15575/jw.v4i2.4718.

${ }_{5}$ Hasse Jubba, "Dinamika Hubungan Islam Dan Agama Lokal Di Indonesia: Pengalaman Towani Tolotang Di Sulawesi Selatan," Wawasan: Jurnal Ilmiah Agama Dan Sosial Budaya, vol. 1, no. 2 (August 2016), pp. 179-86, https://doi.org/10.15575/ jw.v1i2.744.

${ }^{6}$ Deden Sumpena, "Islam Dan Budaya Lokal: Kajian Terhadap Interelasi Islam Dan Budaya Sunda," Ilmu Dakwah: Academic Journal for Homiletic Studies, vol. 6, no. 1 (2012), pp. 101-20.

7 Hanum Jazimah Puji Astuti, "Islam Nusantara: Sebuah Argumentasi Beragama Dalam Bingkai Kultural," INJECT (Interdisciplinary Journal of Communication), vol. 2, no. 1 (2017), to avoid dualism between religion and culture, as Alifuddin's research results concluded that the Butonese people positioned Islam as equal to local elements. ${ }^{8}$

Likewise the concept of Tolaki marriage, the Tolaki community combines Islamic law with Tolaki culture (the Kalosara concept) in marriage. Based on the above perspective, the researcher intends to carry out research related to the struggle between Islamic law and local culture that occurs in the historical space of the Tolaki people. Through this study, the author will prove a legal struggle between Islam with local culture in historical space. The Tolaki community is a dialectical process of rhythmical as the embodiment of a way of thinking religiosity that no longer takes the form of authentic and pure of religion and trying to be a bridge for both religion and local traditions.

\section{Method}

This research focuses on the phenomenon of marriage in the Tolaki community based on the perspective of Islamic law and customary law. This research uses a qualitative approach with a case study type. In this case, data collection is obtained through interviews, observation, and documentation. Meanwhile, the data analysis used Miles and Huberman's analysis.

\section{Results and Discussion \\ Socio-Historical and Cultural Background of the Formation of the Tolaki Marriage Fiqh Tradition}

The Indigenous Tolaki marriage first occurred in Southeast Sulawesi precisely in Wuta Konawe during Wekoila era, which was known among observers of Tolaki culture as Pekukuno Wuta Kanawe. Furthermore, Pekukuno Wuta Kanawe has been divided into three parts, namely: Pekuku Taenango, Pekuku Tula-Tula (Tenango), and Pekuku Mbine Kuku. In the Ranomeeto version of Sangia I Wekoila, it is usually called Anawai Ngguluri

pp. 27-52; Ainul Fitriah, "Pemikiran Abdurrahman Wahid Tentang Pribumisasi Islam," Teosofi: Jurnal Tasawuf Dan Pemikiran Islam, vol. 3, no. 1 (2013), pp. 39-59; Nurhuda Widiana, "Pergumulan Islam Dengan Budaya Lokal Studi Kasus Masyarakat Samin Di Dusun Jepang Bojonegoro," Jurnal Theologia, vol. 26, no. 2 (2015).

${ }^{8}$ Muhammad Alifuddin, Islam Buton: Interaksi Islam Dengan Budaya Lokal, (Jakarta: Balitbang Depag RI, 2007), p. 6. 
which descends from heaven to earth. "Tudu Ari Wawo Sangia Wawo molinga Mbuendo Tolaki iwuta Konawe". 9

From various local sources, it is stated that the existence of the Tolaki kingdom as a country led by a king began to exist in the early $\mathrm{XI}$ century or estimated $1150 \mathrm{M}$ which at that time coincided with the establishment of several Hindu-Buddhist kingdoms in several places on Java, Sumatra, Kalimantan, and Sulawesi islands. ${ }^{10}$ The logical consequence of the absence of a social and cultural value system in the form of law at that time caused chaos and uncertain social conditions. At that time, the uncertain socio-political atmosphere of the Tolaki community is a logical implication of the absence of unity among regional leaders.

The Tolaki community who lived at that time only guarded their respective territories, even they often attacked one another. At such this condition, communication did not go well or even completely cut off. ${ }^{11}$ Wekoila explained that kalo ${ }^{12}$ is a magic object that holds extraordinary power. If used to rule, it could restore the atmosphere and conditions of that time on earth in Konawe. Besides, an object of kalo can restore the situation on Earth. Konawe will be safe, peaceful, orderly, and reunited as before the chaos. ${ }^{13}$ The inauguration of Wekoila as a king and an object kalo as a symbol of unity and unification for the Tolaki tribe had a positive impact on people's lives at that time.

\section{Kalo in the Tolaki Marriage}

Tolaki people still consider kalo as a sacred object. The existence of kalo can unite either the desires or protecting the human rights of every member of the Tolaki community. Marriages of Tolaki people from the past until now are not valid or recognized if Kalosara tradition has not been held. Kalo is an object in the form of a circle, circular ways of remembering, and meetings or activities with the actors form a circle. As a

9 Nurdin Abdullah, Adat Perkawinan Tolaki: Peropu'a, (2013), p. 19.

${ }^{10}$ Muslimin Su'ud, "Kepemimipinan Adat Kalosara Pada Masyarakat Tolaki Di Kabupaten Kendari” (Kendari: Balai Penelitian FISIP UHO, 1998), p. 19.

${ }^{11}$ Muslimin Su'ud, "Kepemimipinan Adat Kalosara..., p. 19.

${ }^{12}$ Muslimin Su'ud, "Kepemimipinan Adat Kalosara..., p. 7.

${ }^{13}$ Muslimin Su'ud, "Kepemimipinan Adat Kalosara..., p. 7. circular object, kalo is made from rattan, and some are made of other materials such as gold, iron, silver, thread, white cloth, roots, pandanus leaves, bamboo, and so on. ${ }^{14}$

Kalasara consists of 3 parts, namely: (1) kalo, in the form of a circle of three rattan wrapped around, (2) a white cloth as a lining, and (3) siwoleuwa, which is a rectangle woven from palm leaves (Interview, the head village of Wekoila). All of the three will be meaningless if they stand alone and do not function customarily unless the three of them are united in an arrangement with the structure as the bottom container in the form of simoleuwa. Then, it is coated on top with a white cloth and on top of these two containers are placed kalo.

Based on the material and its benefit, the other events also uses kalo as a tool for the traditional wedding ceremony, conveying family party invitations, an important guest welcoming ceremony, a king's inauguration ceremony, a peace ceremony for all disputes, conveying suggestions/ opinions to officials by several figures. In addition, the community also uses it in the stage metiro (seeking information or figuring out a girl who will be a candidate for the future daughter-law). Based on the results of the collected information, the family will determine the choices that will be processed due to its stages.

Regarding the importance of kalo in a marriage, if there is no kalosara in every ceremony in a series of marriages, it will be invalid. In other words, there is no marriage without kalosara. The kalosara used in marital affairs is called kalosara mbendulu (kali of a customary marriage). The purpose of using kalosara in a Tolaki marriage is to strengthen kinship among the big family and also to bind relationships with groups of relatives.

\section{Fiqh of Tolaki Marriage}

There are mepakawi or medulu at a wedding ceremony. Its process is preceded by many stages. Ideally and normatively, there are five stages carried out at a marriage, namely metiro stage (reviewing the future wife), mondutudu stage

${ }^{14}$ Abdul Rauf Tarimana, Kebudayaan Suku Tolaki: Seri Etnografi Indonesia, (Jakarta: Balai Pustaka, 1989), p. 7. 
(introductory proposal), meloso'ako stage (real proposal), mondongo niwule stage (proposing) and) mowindahako stage (ceremony of marriage). However, as the time progress, it has been simplified into three stages, namely monduutudu, mondongo niwule, and mowindahako. Monduutud stage is a proposal procession, mondongo niwule during the proposal process, and followed by mowindahako in the wedding procession which is attended by both the bride and groom and their families.

Marriage is a suggestion from Allah Swt that people take care of their life and control their sexual reproduction in a way that is acceptable and based on religious standards. It is the essence of men and women that has a natural need for each other. Marriage is to achieve the goal of human life and to maintain its continuity. The Tolaki tribe in the wedding ceremony system has its figh, namely, several things must be fulfilled, the five stages. These stages require a sacrifice of time and energy. The first stage, Metiro (investigating future wife). The second, Mondudutudu (introductory proposal). The third, melosoako (real proposal). The fourth, mondongo niwule (proposed). The fifth, Mowindahako (implementation of the marriage contract).

The five steps above must be carried out by the future groom. Otherwise, he might get a penalty object in their marriage such as a trading system at that time. However, as time progress, it seems rather rare to do even at the third stage, melosoako, or just go forward to mondongo niwule stage and the process moindahako or marriage. ${ }^{15}$ The important role of all these stages is the procession of sara or kalosara which are officially displayed to the family of the future groom. According to Rauf Tarimana, the above series of marriage system processes without a kalosara, a ceremony in marriage is invalid. ${ }^{16}$

Kalo is a cultural focus that serves as a symbol of integrating elements of Tolaki culture. Physically, its material is three small rattan threads which are wound according to their size and with three ends. It has a certain meaning. The first knot is

15 Bausala Tamburaka, Hukum Adat Perkawinan Tolaki, (Kendari: Balai Penelitian FISIP UHO, 2012), 36.

${ }^{16}$ Bausala Tamburaka, Hukum Adat Perkawinan..., p. 37. the king and the government. The second knot is traditional leaders and figures. The third knot is among the people and the others. The use of kalosara is always equipped with a woven container from palm-leaf stalks and a white cloth as the base of this container. The white cloth means the ruler and the government while the woven container means the community.

The marriage process for the Tolaki people has a very important meaning. It is full of values: social, cultural, and religious values. The uniqueness of the Tolaki marriage system is highly visible through its manifestation in the practice and appreciation of marriage concerning its social, cultural, and religious beliefs. Based on the social point of view, marriage in the Tolaki Tribe is Mesarapu which means clumping together. It is a family fellowship between one family and another. In terms of cultural marriage perapua in Tolaki community includes a complicated procedure and reference due to performing systematically. This marriage has been passed down from generation to generation, called the "Customary Law Community" with the custom kalosara as the vein.

The use of kalosara traditional objects in Tolaki traditional marriage which plays a very important role here is the two traditional instruments called Tolea and Pabitara. Their position is as "directors" in regulating the course of "Mombesara" to regulate customary sequences or called "tetanggano sara". Their function greatly determines the success of the traditional wedding ceremony. So, it is naturally called tolea-pabitara as the spearhead of the implementation of the wedding ceremony. Both customary actors have to do the content of the custom called "popolo" to be carried out when holding a traditional wedding ceremony. The content of the custom must be complete as the prevailing customary provisions cannot be less due to the custom. If there is less, they will be subject to get penalties or it may be a rejection of the customary leaders that consist of Pu'utobu, Tonomotuo, and those representing local government.

There are four main traditional principles that the contents of the custom must be fulfilled. First, Pu'unokasu which means the main content of the custom which consists of 1) a traditional buffalo, 
2) a traditional gong, 3) a piece of gold jewelry for women, 4) one piece of white cloth. The requirements 1 to 3 are substituted @rp.25,000, unless the white cloth should be displayed. Second, Tawano Kasu means 40 traditional sarongs. Third, Ihino Popolo means a set of prayer tools and cash that known as the dowry. Fourth, Sara Peana means traditional women's clothing as a form of appreciation for parents (mothers) for their care.

The reaping of the dowry from four stages due to the conduct rules played by Tolea-Pabitara. The point is to reveal the 4 main contents of the customs presented by Tolea from the male family as follows: First, a white cloth symbolizes the sacred relationship between the two families. Second, a customary buffalo is a symbol of the wider and larger ritual relationship between the two families. Third, a traditional gong whose sound is distant symbolizes the two families of always being harmonious and peaceful. Fourth, a traditional golden rope symbolizes the unity and integrity of the two family families will always be tied with friendship ties. These are the four main principles of custom as a symbol of the honor status of the two families based on the tradition of the Tolaki tribe's marriage.

\section{The Struggle Form between Islamic Law and Tolaki Culture in the Marriage}

Islam since its existence on this earth has played its role as one of the most important forms of the universe. It, of course, brings Islam as a form of religious teaching capable of protecting the diversity of mankind on earth. Islam as a universal religion does appreciate the existence of culture in a society so that the presence of Islam amid society is not contradictory. Islam is close to social life. This fact proves Islam as flexible teaching in understanding the living conditions of a society.

It also happens in the Tolaki community. The structure of the Tolaki indigenous people in Southeast Sulawesi is determined by genealogical factors patrilineally with a combination of the roles of the father and mother in the calculating lineage. Also, territorial factors determine the structure of village communities and joint territorial communities of several villages. The kinship system in Tolaki society is determined by the batih family or well- known as a family clump (O rapu). Thus, marriage in the Tolaki community greatly determines the formation of the community structure that comes from the family clump. A married person means he/she forms a new family or household. ${ }^{17}$

The kinship system in the Tolaki community is not limited to a single-family which only consists of a father, mother, and children. The Tolaki people recognize three terms for this kinship system, namely meohai, anamotua, and pinetoono. Meohai means all individuals group together in the environment of ties of sibling relations, cousins up to three times and within the environment of one ancestral origin either from the paternal line or the maternal line. Anamotuo refers to all individuals grouped in cousin ties up to three times from father/mother and grandparent and so on up to the seventh tier. Pinetoo is all individuals who group within the environment of cousin ties up to three times from brother-in-law, in-laws, fatherin-law/mother-in-law, grandparents, and so on up to the seventh layer. ${ }^{18}$

Besides that, the Tolaki community also knows the terms meolakiana and meombue that refer to relatives. Meolakiana is all individuals who group in the sphere of relationship between all uncles and aunts both siblings and cousins up to three times the father and mother with all biological nephews and cousins up to three times. Meombue is all individuals who group in the word relationship between all grandparents both siblings and cousins up to three times that of grandparents and grandmothers and all grandchildren/greatgrandchildren both siblings and cousins up to three times that of grandchildren/great-grandchildren). The Tolaki people call the relationship mentioned above with the term asoiwoiaria'a or originating from one water source, one ancestor.

The batih family is very decisive in the implementation of traditional marriage especially in determining who can and cannot marry. This problem also applies to the prohibition of incestuous marriages in the Tolaki community. local customs hate incestuous marriages and the

\footnotetext{
17 Abdul Rauf Tarimana, Kebudayaan Suku Tolaki..., p. 7

${ }^{18}$ Tim Kebudayaan Sultra, "Adat Dan Upacara Perkawinan Daerah Sulawesi Tenggara" (Jakarta: Badan Pencatatan Kebudayaan Sulawesi Tenggara, 1979), p. 21.
} 
perpetrators receive customary sanctions. In the past, the Tolaki community was known as a social stratification system. It was inherited from the reign of the Konawe kingdom and the Mekongga kingdom. At that time, community grouping was based on descent and land ownership. There are three social stratification systems known, namely the aristocratic layer (anakia) that also known as pu'onuokasu (parent tree) which means protector or leader; the native layer, the owner of the country (too wonua) and often referred to as toonomotuo (elder person) or ata wonua (country servant) which means state servants, ordinary people, residents (toonodadio); and the slaves or ata . ${ }^{19}$ The social stratification system in Tolaki society was very influential in social relations and government during the Konawe and Mekongga kingdoms. It has a considerable influence in their daily interactions, including in the tradition of marriage. For instance, the prohibition on marriage between Taragolongan and other groups.

In Tolaki community, a man who marries a woman from the aristocratic class is called moruhuowuku. With the payment, the man is raised to the same degree as the woman or it is also called mo-oliobeli (mooli: buy, obeli: blood). ${ }^{20}$ With the entrance of Islam into the area, the social stratification system based on descent and land ownership becomes vague and is replaced by a social stratification basis based on other social levels, such as background and education level; and economic level (a type of profession). The social layering is the basis for the formal coating which is increasingly visible in the daily social system.

In short, the social stratification system in Tolaki society has undergone a shift due to various things, including the entry of Islam into the region and the influence of the education of its people. Heredity and land ownership are no longer the only determinants of a person's respect in society. A hereditary aristocrat will not get recognition from society if he/she does not have anything economically and or does get any education. On the other hand, the slave class who used to be a servant of the aristocratic class can be an honorable person because of the education

\footnotetext{
${ }^{19}$ Abdul Rauf Tarimana, Kebudayaan Suku Tolaki ..., p. 199
}

${ }^{20}$ Tim Kebudayaan Sultra, “Adat Dan Upacara..., p. 24 they take.

Islamic teaching is a source of value for the formation of love for Islamic culture in the Tolaki community. The love of culture appears in the form of ideas which then form Islamic social institutions. The outermost side of these cultural ideals forms cultural objects that can easily be identified whether they contain Islamic cultural ideals or not. Meanwhile, the deepest side, although it is more abstract, the form of a social life system that makes Islam the main reference seen.

In historical records inherited generation to generation, it is stated that Islam was present in the Konawe kingdom during the reign of Sangia Inato (Mokole Tebawo) at the end of the XVI century, or approximately 16 years after the Buton Sultanate accepted Islam. As the presence of Islam in other areas, in the Kingdom of Konawe, Islam exists through a process of preaching carried out by scholars and preachers who deliberately come to this area. The preacher who gave a touch of Islam in the early days was a preacher from the Buton sultanate named La Embo. The first areas that get Islam preaching in Konawe are the coastal areas. Based on several sources, the Wawonii archipelago was the first center for the spread of Islam in Konawe. Since Wawoni'i became the base area for Islamic broadcasting, the island has begun to be visited by people to study Islam. The geographical location of Wawonii which is on the shipping route across Sulawesi makes this area even more visited.

The presence of Islam in Konawe has created a new social and cultural environment in the region so that values are transformed. Although in the early days, Islamic values were not completely used as a source of reference for the socio-cultural system in the Konawe people. It is assumed that Islamic values have infiltrated and mingled with the traditions and culture of the local community. By assimilating the existing values, then slowly but sure Islam instills its influence on the environment and the cultural social system of the local community. At the time of King Konawe XXXIII known as Lakidende who came to power in 1641 , the Konawe kingdom declared officially adhering to Islam.

The proclaiming of Islam as the indigenous 
religion for the people of Konawe during the Mokole Lakidende era, Islam has spread to all corners of the land of Konawe. Thus, the development of Islam runs smoothly and quickly. The conversion of local people to Islam is not a problem, because, at that time, Islam became part of the King's policy. The presence of many Islamic teachers and preachers from the Sultanate of Buton at the request of King Lakidende signs the development of Islam. Tiworo Buton Moji named LaOde Teke led the preachers to teach and broadcast Islam at the center of the Konawe Unaaha Kingdom.

Two assumptions cause Islam to be a part of the life of the Tolaki people. First, the form of Islamic teaching is easily digested and understood as simply as the cultural character of the Tolaki people. Second, the culture that covers Islamic teachings is a culture that can easily synergize with Tolaki culture. Therefore, when the process of Islamization in the Konawe land spread, Islam indirectly formed an identity into Tolakian that was naturally integrated into daily behavior as well as becoming the permanent identity of the Tolaki people. Based on the word of Allah Swt in Q.S. al-Baqarah [2]:: 134, 141, 148, Q. S. Yûnus [10].

"Then We revealed the Book to you ( $O$ Muhammad!) with Truth, confirming whatever of the Book was revealed before, and protecting and guarding over it. Judge, then, in the affairs of men in accordance with the Law that Allah has revealed, and do not follow their desires in disregard of the Truth which has come to you. For each of you We have appointed a Law and a way of life.80 And had Allah so willed, He would surely have made you one single community; instead, (He gave each of you a Law and a way of life) in order to test you by what He gave you. Vie, then, one with another in good works. Unto Allah is the return of all of you; and He will then make you understand the truth concerning the matters on which you disagreed". (Q.S. al-Mâ'idah [5]: 48).

Explicitly, the above verse indicates that each community will be given methods and instructions in actualizing their religious way. Seeing the marital status of the Tolaki people, what Islam is understood is of course in line with the conditions of the Tolaki people. It means that Islam as a value system provides feedback to culture by giving certain forms and colors, on the contrary as a cultural system, almost inevitably has provided feedback to Islam by providing opportunities for the development of views, understandings, religious experiences, and certain styles in actualizing its diversity.

\section{Factors Influencing the Process of the Struggle of Islamic Law and Local Culture}

As previously mentioned, Islam entered the archipelago directly in contact with people who already have religion and culture. The belief that Buddhism-Hinduism and animism/dynamism as relics of ancestors have existed. Islam entered the royal society which was Hindu Buddhist whose people were still very friendly to their previous beliefs. Then the process of Islamization in the form of adaptation, assimilation, acculturation occurred slowly but surely in all aspects and joints of community life. It went well even the conflict between Islam as a newcomer religion and well established Buddhism-Hinduism or animism/ dynamism happened. Between Islam and HinduBuddhism, there seem to have similarities in some respects, but there are also many basic differences and variations.

In the marriage process, the intersection between Islam and local culture especially in the Tolaki community is carried out. It shows that Islam fits perfectly into the local culture in which it expresses itself, contrary to the views of some Muslims. The introduction of Islam to the Tolaki region has changed significantly since the 16th century. For example, Islamic teaching that the community still practices today such as stoping drinking liquor (Pongasi), marrying more, and stoping worshiping gods or Sangia. The teaching emphasizes monotheism, namely affirming Allah SWT. The harmonious relationship between Islamic teachings and Tolaki culture occurs, especially in the traditional Tolaki marriage procession. This process of inculturation shows in the marriage procession in which both Islamic elements such as P3NTCR, the Head of Religious Affairs (KUA) and traditional elements such as Pu'u tobu and pabitara (male spokesman), Tolea (spokesperson 
for the party women) must be present at the event. In this traditional wedding ceremony, the relationship between Islam and Tolaki culture shows adaptation, mutual understanding, and conversation with each other. It means that there are no dominant or mutually dominant camps in this cycle of marriage, Islam, and traditions. In conclusion, when Islam and the Tolaki tradition have an equal position, conflict is very rare. The tensions arise when Islam is positioned as domination and eliminate the existence of local culture. It broke the harmonization between local culture and Islam as has been well established so far.

In the traditional marriage ceremony procession regarding the Tolaki marriage system,), Islamic values are present in the marriage contract fragment which is arranged accordingly and becomes an integral part of the Mowindahako traditional ceremony fragment as Traditional Marriage (Abdurrauf Tarimana, 1993). In the marriage contract fragment, a procession of marriage pillars was based on Islamic teachings such as the pronunciation of the sentence istigfar and two sentences of syahada, the sermon of the marriage, the contract, as well as the recitation of marriage prayers and shighat $t a^{\prime}$ lik. In the fragment of the Mowindahako traditional ceremony is held before the marriage contract. Both tolea (Adat Ambassadors) and pabitara (Traditional Spokespersons) guid the procession of using the kalosara in which begins with greetings and basmalah, and ends with Alhamdulillah and closing greetings. It happens in the communication system because the external cultural effect manifested by rejection or silence can persist and be picked in all cultures. Willingness to adapt and incorporate new cultures into indigenous cultures is also important. In the historical context, as happened in the history of spreading Islam to the archipelago, we can study Islam and its relationship with the local culture. There are three patterns of spreading and forming Islamic groups in different regions of Southeast Asia.

In the context of contact between Islam and local culture, four patterns of Islamic social formation may occur in the interaction process. The first is the Islamization pattern. The second is the indigenous pattern. Both are two variants of an integrated pattern between Islam and local culture. The third is the negotiation pattern and the fourth is the conflict pattern. Both are variants of dialogue patterns.

The struggle between Islam and local wisdom has made Islam so multi-faceted. When it faces variants of local culture, it immediately takes a part in various symbiotic processes that enriched each other. The emergence of various variants of Islam: Islam-Java, Islam-Sasak, Islam-Malay, IslamMadura, Islam-Coastal, Islam-Poliwali, Islam-Ambon, Islam-Padang, Islam-Banjar, Islam-Bima, and so on illustrates that Islam always has a local color when approaching a community. Likewise, there are Islam-Arab-Islam-Iran, Islam-China, Islam-America, Islam India, Islam-Indonesia, and so on in which those have their truth construction. Thus, we can come up with a hypothesis for the concept of "Tolaki Islam and Islam Tolaki". In Indonesia, the gono gini system exists in Kompilasi Hukum Islam (KHI or the Compilation of Islamic Law) also adopts a dialectic of Islamic law with a growing tradition in Indonesia. This is the old ideal of Islamic law scholars in Indonesia who want figh with an Indonesian personality.

The existence of reciprocal acculturation between Islam and local culture appears in a principle or basic provision in the science of ushul al-figh that tradition is a law (al 'adah muhakkamah), or more fully, tradition is sharia (al-'adah syariah muhakkamah). It means that the customs and habits of a community namely local culture are the source of law in Islam. As a norm, rules, and all activities of Indonesian society, Islamic teachings have become a pattern for society to adopt. In this context, at the same time, Islam as a religion has become the culture of Indonesian society. On the other hand, the local culture in society does not automatically disappear with the presence of Islam. Some of these local cultures continue to be developed by adopting Islamic colors. Then, it forms "cultural acculturation", between local culture and Islam.

The combination of the two cultures produces a distinctive culture. A local image is very possible to be realized because, in every encounter between two cultures, humans form, utilize, change, and 
compose things that best suit their needs. With this starting point, in the cultural framework especially in the process of acculturation, local genius is born namely the ability to absorb while selecting and actively processing the influences of the culture that comes. Thus, there are new unique creations formed in the territory of the nation that carries the culture. Therefore, the dialectic between Islamic law and local culture in the marriage system of the Tolaki people and the extent to which it is related to Islam is seen in the framework of the interaction theory as described. It is important to map the form of marriage norms that develop in that society. To get the mapping earlier, we should observe the ritual practice or marriage ceremony. Taking into account the practice of marriage rituals manifested in the Tolaki community, the author views that the whole system of marriage law in Tolaki society phenomena is divided into two categories, namely: 1 ). The law that originates from Islamic teachings as outlined and reflected in the ritual of the marriage contract, and (2). Tradition law is a norm that exists in the marriage ceremony which they have inherited from generation to generation. It is divided into two: (a) Values which are a pre-Islamic heritage, and (b) Norms that are manifested from the reflection of understanding the symbols that live in the present. The mapping aims to see the level of interaction between Islamic law and local culture. Besides, interaction as a process of relationship that occurs between two different elements will produce several possibilities namely Islam being rejected by local cultural values or synthesized and integrated with local values in the local community. It is reflected in various marriage ritual practices such as wedding rituals that use Islamic symbols.

In the marriage of the Tolaki Tribe, a combination of culture and Islam occurs at the position of the Kalosara in Tolaki traditional marriage that must exist. The Kalosara custom procession is customary law or norm as a tool of "legitimacy" or the legalization of the customary marriage itself. The point is to "build and cultivate family clumps" and to strengthen ties that may have been lost. Carrying out the kalosara procession is a symbol of the highest respect for the Tolaki tribe. Kalosara embodied in sara or o'sara, the customary values and norms that must be obeyed. It is the reason why the traditional Tolaki wedding procession must be preceded by mowindahako. Then continues to the wedding ceremony based on Islamic law, namely the reading of the marriage contract and ljab Kabul. It is religious norms or creed norms.

Besides the marriage due to Islamic marriage law, regarding the view of the Tolaki people, the marriage is not valid without the Tolaki marriage customary law ceremony performed in the five stages mentioned before. The purpose of implementing customary law is to strengthen the position of customary law communities as a philosophical motto in Tolaki's poetic state "Inae Kona Sara lyeto Pinesara Inae Lia Sara lyeto Pinekasara". It means that whoever respects tradition will be respected, whoever does not respect tradition will not be respected.

\section{Conclusion}

The struggle of Islamic law and the marriage of the Tolaki tribe lies in the social stratification system. It was inherited from the reign of the Konawe kingdom and the Mekongga kingdom. At that time, community grouping was based on descent and land ownership. There are three social stratification systems, namely 1 ) the aristocratic layer (anakia) or known as pu'onuokasu (parenttree) which means protector or leader; 2) the native layer, the owner of the country (too wonua) and often referred to as toonomotuo (elder person) or ata wonua (country servant) which means state servants, ordinary people, residents (toonodadio); 3) slaves (ata). The social stratification system in Tolaki society has shifted due to the entry of Islam into the region and the influence of the education of the people. The presence of Islam in the Tolaki Society has created a new social and cultural environment in the region. It constructs a transformation of values. Although nowadays Islamic values are not the only source of reference for the socio-cultural system in the Konawe people, these Islamic values have infiltrated and mingled with the traditions and culture of the local community. The assimilation of existing values, slowly but surely Islam will instill its influence on the environment and the sociocultural system of the local community. 
The factors that influence the struggle of Islamic law and marriage culture in the Tolaki community are that the relationship between Islam and Tolaki culture. It shows adaptation, mutual understanding, and conversation with each other. There are no dominant or mutually dominant camps in this cycle of marriage, Islam, and traditions. In conclusion, when Islam and the Tolaki tradition have an equal position, conflict is very rare. The tensions arise when Islam is positioned as domination and eliminate the existence of local culture. It broke the harmonization between local culture and Islam as has been well established so far. Besides the marriage based on Islamic law, for the Tolaki people, the marriage is not valid without the Tolaki marriage customary law ceremony performed in the five stages mentioned before. The purpose of implementing customary law is to strengthen the position of customary law communities as a philosophical motto in Tolaki's poetic state "Inae Kona Sara lyeto Pinesara Inae Lia Sara lyeto Pinekasara". It means that whoever respects tradition will be respected, whoever does not respect tradition will not be respected.

\section{Pustaka Acuan}

Abdullah, Nurdin, Adat Perkawinan Tolaki: Peropu'a, 2013.

Alifuddin, Muhammad, "Fikih Keraton: Diskursus Hukum Islam Dalam Bingkai Tradisi Lokal Masyarakat Buton." Istimbath, 2014.

—, Islam Buton: Interaksi Islam Dengan Budaya Lokal, Jakarta: Balitbang Depag RI, 2007.

Astuti, Hanum Jazimah Puji, "Islam Nusantara: Sebuah Argumentasi Beragama Dalam Bingkai Kultural, " INJECT (Interdisciplinary Journal of Communication) 2, no. 1, 2017.

Azra, Azyumardi, Konteks Berteologi Di Indonesia: Pengalaman Islam. Jakarta: Paramadina, 1999.

Fitriah, Ainul, "Pemikiran Abdurrahman Wahid Tentang Pribumisasi Islam," Teosofi: Jurnal Tasawuf Dan Pemikiran Islam 3, no. 1, 2013.
Jubba, Hasse, "Dinamika Hubungan Islam Dan Agama Lokal Di Indonesia: Pengalaman Towani Tolotang Di Sulawesi Selatan," Wawasan: Jurnal Ilmiah Agama Dan Sosial Budaya, vol.1, no. 2 (August 2016), https:// doi.org/10.15575/jw.v1i2.744.

Miharja, Deni, M. Mulyana, and Ahmad Izzan, "Islam, Ethnicity and Cultural Politics of Identity: The Religiousity of Betawi Muslim in Jakarta," Wawasan: Jurnal Ilmiah Agama Dan Sosial Budaya, vol. 4, no. 2 (December 2019). https://doi.org/10.15575/jw.v4i2.4718.

Rahmawati, Rahmawati, Kasim Yahiji, and Muh Rusli, “Mopo'alati Tradition In The Coastal Muslim Community At Molotabu Beach Bone Bolango District, " Wawasan: Jurnal Ilmiah Agama Dan Sosial Budaya, vol. 4, no. 1 (December 2019). https://doi.org/10.15575/ jw.v4i1.4080.

Su'ud, Muslimin, “Kepemimipinan Adat Kalosara Pada Masyarakat Tolaki Di Kabupaten Kendari." Kendari: Balai Penelitian FISIP UHO, 1998.

Sumpena, Deden, "Islam Dan Budaya Lokal: Kajian Terhadap Interelasi Islam Dan Budaya Sunda." Ilmu Dakwah: Academic Journal for Homiletic Studies, vol. 6, no. 1, 2012.

Tamburaka, Bausala, "Hukum Adat Perkawinan Tolaki, " Kendari: Balai Penelitian FISIP UHO, 2012.

Tarimana, Abdul Rauf. Kebudayaan Suku Tolaki: Seri Etnografi Indonesia. Jakarta: Balai Pustaka, 1989.

Tim Kebudayaan Sultra, "Adat Dan Upacara Perkawinan Daerah Sulawesi Tenggara, " Jakarta: Badan Pencatatan Kebudayaan Sulawesi Tenggara, 1979.

Widiana, Nurhuda, "Pergumulan Islam Dengan Budaya Lokal Studi Kasus Masyarakat Samin Di Dusun Jepang Bojonegoro." Jurnal Theologia, vol. 26, no. 2, 2015. 